\title{
Activation of Community Television and its Influence on Students' Creative Thinking Level
}

\author{
Michal Aflalo, Baruch Offir \\ School of Education, Bar-Ilan University, Ramat Gan, Israel. \\ Email: offir-e@zahav.net.il \\ Received April 22 $2^{\text {nd }}, 2010$; revised May $18^{\text {th }}, 2010$; accepted May $20^{\text {th }}, 2010$.
}

\begin{abstract}
The goal of the research was to examine whether a relation exists between students' experience in community television and changes in their creative thinking ability. Community television is a tool that enables the expression of wishes, opinions, ideas, thoughts, experiences and skills via community television broadcasts. Learning in community television affords experience with different types of activities. Each role requires different skills and characteristics. In the present research we used job analysis to characterize the different experiences within the framework of community television. Job analysis is a technique for presenting detailed information on activities carried out within the framework of the job. The job analysis used in this research is based on a list of abilities, traits, skills and fields of knowledge from which the person suitable for the role should be chosen. The influence of students' experience in community television on their creative thinking level was examined, as well as whether different experiences in community television have a different effect on the students' creative thinking. The research population included 157 subjects who underwent a set of tests for evaluating their creative tendency (curiosity, originality, and general creativity score). All subjects experienced the production of a movie, while learning the secrets of television production and experiencing production roles according to their personal choice (director, editor, photographer, actor). The choice of experience was made according to each student's personal choice, with the aim of enabling the expression via multiple intelligences. The tendency to creativity was measured using a tendency to creativity questionnaire [1]. After the learning and the process of producing the movie, the subjects took the same set of tests in order to examine the change that took place following this process. They were also interviewed in order to discover their opinions and feelings regarding the process they underwent. Analysis of the tests and the interviews indicates that students who experienced community television production roles improved their creative tendency level in all experience roles: director, editor, photographer and actor. An open experience system that integrates different levels of experience and active learning, autonomous learning and affords expression for multiple experiences with the aim of creating a common project in which all contribute their share towards the final product can develop the tendency for creativity among students.
\end{abstract}

Keywords: Job Analysis, Creative Thinking, Community Television, Learning by Doing

\section{Theoretical Background}

We have been researching different variables that may help implement change in learning systems for over thirty years $[2,3]$. The present research examined the influence of the process of "learning by doing" on students' creative thinking ability.

"Creative" means bringing something into being that did not exist previously, the ability to create a new, original, unexpected and different creation [4-7]. Creativity is a dynamic process. It is ongoing and developing. Creative processes are based on the ability to create new connections while using new schemes of thinking, new ideas and new conclusions via experiences that until that time were not connected to each other. Creativity is a trait that enables us to deviate from the familiar boundaries, and is perceived as a guarantee for flexibility of thought expressed in affording original solutions and raising new ideas $[7,8]$. Creativity is a manipulative action of converting the existing, reshaping it, and creating new connections in order to solve a problem. It is actually a kind of unconventional use of existing knowledge, degradation of existing patterns and unexpected use of their components to create new patterns.

Creative thinking is a thinking pattern that tends to lead to creative results, i.e. original, continuous and congruous results according to the criteria of a particular field. Creative thinking enables us to activate the trait of 
creativity in a systematic manner. It is a conscious and deliberate system that refers to all types of information and its sources, while constantly searching for alternatives. Creative thinking actually refers to the human intellect. Creativity is a kind of intelligence. The need for creativity is found in places where a new idea is needed, when there is a problem, crisis or conflict, when other approaches have failed and where a new idea may create an opportunity that can afford an advantage or benefit. Any occasion that necessitates thinking, needs information, analysis and creativity. Only teaching that includes active thinking will develop independence and creativity in the students that will lead them to effective learning. The classroom should turn into an environment in which students can develop "high order thinking," i.e. active participation in collecting, expanding, reconstructing, interpreting, evaluating, transferring and reaching conclusions. Since experiencing roles in community television is a kind of active learning, we assume that such an experience will develop a degree of creativity among the students.

Creativity is also courage, since anything innovative and unknown is also not sure and is not compatible with past experiences. Facing a new insight requires daring. Creative thinking is a way of life, a lifestyle that prevents life's depletion of meaning. Research differentiates between a creative personality characterized by abilities and a creative personality characterized by traits. A creative personality characterized by abilities was defined by Guilford [9] and Lowenfeld [10]. They defined creative thinking as branched thinking characterized by intellectual abilities. Guilford defined creativity by researching the structure of the intellect. In his opinion, the abilities that characterize creative thinking, which can be measured, are fluency abilities (amount of responses), flexibility abilities (diversity of the types of responses), originality abilities (uniqueness of the responses), sensitivity abilities (ability to recognize problems), processing abilities (ability to process data), and redefinition abilities (ability to change data and reformulate them). Lowenfeld also differentiated between factors and abilities. The factors that comprise the intellect are sensitivity, fluency, flexibility and originality and the abilities are redefinition, analysis, synthesis and organization.

Torrance [11-13] viewed creativity as a unique cognitive ability. Creative people use the same cognitive processes as others, but in an efficient and flexible manner while having ambitious and sometimes even dangerous goals. Gardner [14] presented creative people as devoted to their work and enthusiastic, exhibiting the need to do something new and with a strong commitment to their final goals and targets.

The traits that characterize the creative personality are explained as two traits that comprise a fundamental condition for this personality: originality and openness to the environment. Nilsen [15] characterized creative people as open, sensitive, curious, playful and with a sense of humor. Smith [16] emphasized additional traits that characterize the creative personality: willingness to take risks, willingness to fail and to learn, internal motivation, satisfaction from work. Many studies report that creative people are characterized by openness to new experiences, growth and development [17-21]. Creative thinking is a conscious ability that helps in the development of new unconventional ideas and in the development of several possibilities for solving a problem. The literature lists six principles for creative thinking:

1) Creative thinking necessitates esthetic and practical standards to the same extent. Creative people strive towards originality, and towards something fundamental and powerful with a broad range of influence $[22,23]$.

2) Creative thinking is dependent on focusing on the goal and on the results to the same extent. Creative people examine goals and alternative approaches at an early stage of the thinking effort, evaluate them critically, understand the nature of the problem and the standards necessary for solving it, are willing to change their approach and later redefine the problem according to need $[24,25]$.

3) Creative thinking is dependent on mobility more than on fluency. Creative people can turn problems into more abstract or more tangible, into more general or more unique.

4) Creative thinking is dependent on work at the edge of the thinker's ability more than at its center. Creative people have high standards. They accept conditions of confusion, uncertainty and high risk as part of the creative process, and learn to perceive failure as normal, interesting and challenging.

5) Creative thinking is dependent on objectivity just as it is dependent on subjectivity. Creative people consider different viewpoints. They reject occupation with final products or intermediary products and return to them at a late stage in order to evaluate them from a greater distance [23].

6) Creative thinking is dependent on internal motivation more than on external motivation. Creative people feel that they choose what to do and how to do it. They evaluate the task they were obligated to perform as an answer by itself, and not as a means for achieving an end, and enjoy the activity, its background and its context [26].

The more the person's thinking is guided by these six principles, the more creative it is. We assumed that experiencing community television production roles demands affording several solutions to a problem, with development of new, original and unconventional ideas while realizing principles of creative thinking. Five characteristic dimensions of creative thinking that touch upon the characteristics of the examined role holders are:

- Meta-cognition: People thinking and learning on 
their own. The students must think about their moves all the time and plan how to advance in light of the results of the action and learning. For example, they must observe the products of the filming in order to decide how the edit. Thinking about the learning is carried out during the entire production process.

- Critical thinking and creative thinking: Critical thinking directed towards creating evaluations of things, and action processes and creative thinking directed towards the creation of creative results. The students must think in terms of the viewers of the movie and create evaluations and changes accordingly along the entire process.

- Thinking processes: The thinking processes are expressed in the design of concepts and principles, in understanding, problem solving, making decisions, research, composing and verbal dialogue. The production process requires the transmission of a message via the movie and therefore requires thinking processes.

- Central thinking abilities: A certain category of abilities has a clear connection to creative thinking, formulation of questions, conclusion and reconstruction. Creating a movie, as mentioned, is a way of asking a question and obtaining an answer. Production of a movie requires formulation of questions, conclusions and reconstruction.

- Relations between fields of knowledge and thinking: A creative personality in one field tends to be creative in other fields as well.

Four levels of creative thinking can be discerned:

1) When the students begin to answer a question, but do not know what follows and cannot continue with the thinking process.

2) When the students give an evasive answer that did not answer the question directly, but is related to it.

3) When the students try to think and create an answer, which is correct or incorrect.

4) When the students refer to the question or the problem with a detailed answer, accompanied by tangible examples and with reference to their life experience [27].

The present research proposes a model for cultivating the thinking abilities and traits that will promote creativity by means of experiencing the fulfillment of roles in community television.

\subsection{Developing the Tendency to Creativity}

All people are creative, although the degree of creativity varies from one person to another. If we supply practice and training, organizational structures and systematic techniques, we can raise the general level of the creative ability. Thus, experience can develop the tendency to creativity. Development of creativity does not take place uniformly. We usually begin our lives as very creative, but at age eight or nine the extent of creativity decreases because of thinking and behavior habits. Guilford [28] indicated an arrest of the development of creativity in the late years of adolescence and its reawakening in the early thirties, years during which the quality of creativity reaches its peak.

Creative thinking can be taught by cultivating patterns of thinking. A deliberate change in creative thinking is possible, but requires a great deal of motivation, energy and the ability to recognize new forms of thinking, feeling and behavior. We claim that experience with community television will develop a certain creative tendency because it is a different pattern of thinking and behavior. Researches indicate an improvement in creativity by training and the development of creative thinking abilities via different teaching methodologies [29]. Experience in community television is, as mentioned, a combination of several teaching methodologies. Numerous approaches to teaching creativity emphasize a diversity of thinking patterns that help break down the structured system of ideas [30-33]. Interdisciplinary teaching serves as a strategy and a tool by the teacher to develop the tendency to creativity in the student. Education towards creativity should expose the students to the taste and texture of the creative inquiry and should strive to cause the students to become enchanted with it. We assume that an environment such as community television will enable creative inquiry and will lead to the development of a tendency to creativity.

The television production process includes many roles (producer, director, editor, photographer, actor, investigator, light or sound person). The present research focused on only four roles (director, editor, photographer, actor). These roles were prominent in the preliminary questionnaire on community television production, as obtained from the report of 45 community television coordinators. The director, photographer, editor and actor comprise an integral part of the television production process. They work in a team and all contribute their professional part to the production of the movie. Each of the students experienced one of these roles during the production process.

The directors direct the movie, position the movie, and give instructions to the other role holders. The directors' main job is to turn the words into pictures, turn the script into a visual picture that will reflect what is written in it and illustrate the text. The directors are supposed to see the final product in their mind's eye.

The photographers, who photograph what they choose, seemingly comprise an "external space" as opposed to the inner world. This space contains unique emotional elements from their inner world, which are created as a response to the circumstances of their lives. Photography itself may have a therapeutic effect and may serve as a spring-board for the youths towards a new type of coping. Photography is a type of observation, a type of process- 
ing of stimuli which originate in reality, affording an interpretation to them that takes place in the brain. The brain organizes the data which it receives in a subjective manner that is dependent on the emotional, personal and cultural context, and is based on the collection of information, learning the components of the reality and constructing fixed patterns that identify them as a result of experiencing them in different situations. Photography enables the photographers to observe and arrange the data, the pictures or reality in a way they choose and thus to create the emotional or personal context of their choice. Dealing in photography as an artistic means enables the students to afford an authentic expression to their identity and express their opinions and approaches towards many issues, while creating order and organization within their inner world [34]. Personality factors such as tendency to creativity, emotional intensity and motivation, will contribute to the quality of the photographs because of the uniqueness and sensitivity that will be added to the final picture, which will turn it from a "picture" into a "creation".

The editors are judged by the ability to realize the director's desires during the editing process and by the ability to observe the "materials" (the raw photographs), by an objective observation and by advising the director how to improve and change things pertaining to the editing of the movie, in order to improve the "final product." Editing movies is a creative field, which necessitates wisdom and feeling. Editing is to know how to activate the viewer, to surprise, shock, excite or frighten. The editors actually cut in order to fuse, fuse in order to cut, cut in order to draw near. What was taken apart is recomposed, will be organized in a special order and at a special rate, with a special sound track. The editors create meaning by changing the order of things. Thus, the editors can influence the style of the movie. The role of the editors is to help the directors exhaust the movie's potential, transmit the story, saying or plot in their unique style. The editors edit by means of an editing system that enables control over the time, the picture and the esthetics of the movie. Personality variables such as tendency to creativity, emotional intensity and motivation will influence the editors' imprint on the quality of the final editing.

The actors must present the text visually, and are supposed to "enter the figure" and personify scenes that will appear real to the viewers. The actors perform a type of dramatic act. In the dramatic act the students take on a role and become someone else. They imitate that person in action and in speech, using real or imaginary objects. The students' speech during acting is imitative speech, or declarations that serve as an alternative to objects, actions or situations. Experiencing dramatic acting enables the students to investigate the social roles as preparation for their participation in the life of the family and the community, while developing the ability to view the world through different eyes. The actors improve their acting ability as they accumulate experience. When participating in different acting roles, their ability to react increases. When acting together with other actors, they become acquainted with the different interpretations which different actors attribute to the same role, and when they act out this role with the same actors in different cases, each acting episode changes shape and becomes something new.

The literature indicates that the goals of dramatic acting include emotional and physical unity, development of social skills and effective communication, encouragement of creativity, imagination and intuition, and processing of emotional contents. Courtney [35] claimed that drama enables all students to cultivate their talents in collaboration with the environment and with the group. Dealing in drama as a spontaneous creative activity removes obstacles, reduces anxieties, increases motivation and perfects the expressive ability. All types of students can be offered a creative dramatic activity for cultivating their natural talents and for affording reinforcements or solutions for their virtues or limitations.

Students who experience community television as actors act a kind of socio-dramatic acting. They take on a role, pretend to be someone else, share the situation with friends and develop social skills via this process. Personality variables such as tendency to creativity and emotional intensity will influence the actors' acting and their ability to persuade the audience of the credibility of their acting.

\section{Research Method}

The goal of the research was to examine the relation between students' experience in community television and their creative thinking level. Does a relation exist between the actual experience and the development of the students' creative thinking ability? What is the difference between the level of creative ability among students who experienced and students who did not experience community television production processes (control group)?

Two research methods were used in order to achieve the research goals. In the first part of the research we collected information from the students using quantitative instruments, because of the experience in using these instruments and the possibility of processing them and because of the strength of quantitative research in reaching conclusions and generalization from information that is based on a large sample of the population. In the second part of the research, information was collected using the qualitative research method, with the aim of collecting information from the subjects and discovering angles and processes that are not obvious. The qualitative instrument in the present study was the focused guided interview, which affords freedom to the interviewer and the interviewee, and enables achievement of a broader 
picture of the researched reality. The qualitative research method had several goals:

1) To supplement and deepen the understanding of phnomena which we identified using the quantitative data of the research.

2) To consolidate and emphasize the psychological characteristics of the role holders, also from the subjects' point of view.

3) To describe behaviors and opinions not expressed in the quantitative research.

Use of the two research methods (quantitative and qualitative) in one research is customary in the research literature and is recommended in studies that examine learning environments, due to the limitation of the quantitative research $[36,37]$. The qualitative research, via the interview, complements and expands the results of the quantitative research. Combined use of both methodologies is also recommended by researchers [38] in order to strengthen the internal and external validity.

\subsection{Sample}

The sample included 157 subjects, boys and girls, youths, from ten settlements with a medium-high socioeconomic status. The settlements were sampled randomly from all the settlements in Israel where there are active groups of community television. These are peripheral settlements, since more community television groups are active in them. The control group was also sampled randomly, from the same districts and from settlements with the same socioeconomic status. The groups are similar in terms of their cultural, economic and social background. 119 students experienced community television production processes and 38 comprised the control group, i.e. students who did not experience the television production processes.

The subjects: The subjects are boys and girls aged 12-16 who were chosen randomly to be part of a group that experienced community television production. The groups were mixed in terms of the ages (12-16). In order to obtain valuable reciprocal actions between the students, prominence of categorizations which dictate separation (boys-girls, age groups, homeroom class) must be abolished. Mixed-age groups can advance the development of all their members, young and older alike. The youths learn that they can be sources of information and help for their peers. The more they experience situations of literacy in the social context, the more complex, deliberate, planned and continuous is the level of their activity, which ends in a solution [39]. Multi-age learning helps the selfadjustment [40].

\subsection{The Research Instruments}

The following instruments were employed for the present research: job analysis according to the competency-based approach and a questionnaire for the tendency to creativ- ity [1].

\subsubsection{Job Analysis}

Job analysis is a technique for presenting detailed information on the activities carried out within the framework of each role and for determining the data required of each worker in order to perform these actions at a satisfactory level. A job is the entirety of the tasks directed towards the achievement of a particular target. The goal of this technique is to collect data and create quality information on the demands of the role. It was developed in order to supply human resources managers with a systematic and tested tool that can help in the creation of quality information on the demands of the role as the basis for the development of the role holders. Job analysis:

- Helps the manager and the worker define obligations and expected results from the role holder and the tasks derived from them.

- Comprises a document that helps direct the workers in their work.

- Defines the importance and the time frame required for the job.

- Supplies the candidates for the job with realistic information on the work (thus reducing the exchange rate).

- Comprises an instrument for examining the need for the role, its authorities and position in the organization.

- Supplies quality information for making skilled decisions.

- Comprises the basis for creating advancement tracts.

There exist several techniques for performing job analysis:

The competency-based approach (CB): Analyses based on a list of the abilities, traits, skills and fields of knowledge, from which the relevant person for the role should be chosen. CB techniques include: 1) the occupationmapping model [41] that maps the motivating potential embodied in the role (the abilities that the role requires), the identity of the role, the meaning of the role, the status of the role, the autonomy of the role and the extent of feedback in the role; 2) job analysis based on occupational reward which is based on a complex instrument composed of 21 measures of occupational reward, i.e. the extent to which the occupation in the role meets the need for achievement, the extent of authority, creativity and independence, etc.

The behavior-based approach (BB): Analyses based on a list of behaviors or processes, from which the relevant behaviors for the role should be chosen.

The performance-based approach (PB): Analyses based on a list of outputs and targets required for achieving the goals and aims of the organization, from which the relevant outputs for the role should be chosen. 
$\mathrm{BB}$ and $\mathrm{CB}$ techniques include: 1) qualitative job analysis, description of the work as tasks and sub-tasks, features of the work and the requirements of the occupation in terms of traits and abilities (verbal description); 2) functional job analysis, description of the work as tasks and sub-tasks with reference to people, data and objects; 3) job analysis based on a structured questionnaire that presents collection and analysis of frequent activities and their grouping into six groups with a common denominator: information, thinking, achieving outputs, interpersonal activities, environment and different aspects pertaining to the job. The questionnaire contains 182 statements that describe the job in these six measures.

Technique that combines all three approaches $(\mathrm{PB}+$ $\mathrm{CB}+\mathrm{BB}$ ): This technique is based on the perception of improvement in performance. The role is perceived as an organizational sub-system. The role therefore has a destination, purpose, organizational environment, superior, suppliers, subordinates, outputs, targets, skills and threshold conditions.

In the present research we used the competency-based approach to job analysis. This is an analysis based on a list of abilities, traits, skills and fields of knowledge, from which the relevant person for the role should be chosen, and is based on Hackman and Oldham [41]. This approach maps the abilities, identity and meaning required by the role.

\subsubsection{Examination of the Tendency to Creativity Using the Rookey [1] Questionnaire}

The creative tendency test is a questionnaire for examining creative tendencies [1]. The questionnaire tests the traits: creative behavior, ability, self-direction, behavior based on values, flexible thinking, original thinking, developed and branched thinking, willingness to take risks, sense of comfort in complex situations, curiosity and fluency of thought. The questionnaire contains 184 statements, where 23 are formulated such that a positive answer means a creative approach and 161 are formulated such that a negative answer means a creative approach. We therefore performed inversion of the scores such that a high score would express creativity and a low score would express lack of creativity.

The questionnaire is divided into two subquestionnaires, a "curiosity" questionnaire and an "originality" questionnaire. The "curiosity" questionnaire contains statements that refer to the desire to know, to learn new things and to be open to others' experiences. The "originality" questionnaire contains statements that refer to original thinking, flexible and branched thinking, thinking fluency and desire to remember new things.

\subsubsection{Scoring}

The subjects were asked to indicate the description of the answer that best describes them on a scale of 1 to 5 , from "not true at all" to "very true." Higher values indicate higher creativity. The reliability of the questionnaire was $\alpha=0.81$. Three measures were created for each subject, two which express curiosity and originality and one general measure. The measures of curiosity and originality were calculated as the means of the answers to the items of the creative tendency, respectively. The general measure for tendency to creativity was calculated as the mean of the answers to all items of the questionnaire. The reliability of the measures was tested as internal consistency according to Cronbach's alpha and was found to be higher than 0.70 for all measures.

\subsubsection{Interview}

A qualitative research instrument was used to understand the conditions under which the behaviors we observed during the experience in community television production occurred, what the subjects felt and the background that led to these behaviors. The interviews were intended to find the meaning which the subjects attributed to things, what they thought about the research topic, what they believe in, what they prefer and what in their opinion influenced the process. By exposing the students' viewpoints we succeeded in understanding internal processes that were not exposed through the questionnaires. We were also able to cross between the students' answers in the interviews and their answers on the questionnaires by the questions: "What do you think developed in you?" and "What do you think caused the improvement?" Seventy randomly-chosen students were interviewed. However, due to incompatibility with the questionnaires (some interviewees did not participate in the first or second part of the research), only 61 interviews were used.

The interviews were performed according to the rules of an open ethnographic interview [42]. These are interviews based on friendly, harmonic and informal relations and enable free flow of information. The interviews were recorded in order to make it easier for the interviewer to maintain eye contact with the interviewee and to enable a pleasant and comfortable atmosphere. The interviews were later transcribed and encoded. They were constructed as a guided and focused interview whose aim was to understand what variables changed in the students and how they felt with this, according to their role in the production. We also asked what variables they thought did not change and why. The questions in the interview were divided as detailed in Table 1.

The interview was held in a friendly informal manner (in order to increase the interviewee's trust in the interviewer). The interviewers had an outline of questions, but their goal was to encourage the interviewees to tell their experiences from the process, describe events and express opinions.

\subsubsection{Analysis of the Interview}

The interviews were analyzed using content analysis [43, 
Table 1. Description of the types of questions asked in the interview

\begin{tabular}{|c|c|c|}
\hline Type of questions according to Spradley [42] & Description of type of question & Questions asked in the research \\
\hline Far-reaching question & $\begin{array}{l}\text { Description of a particular task that the inter- B. } \\
\text { viewee performs }\end{array}$ & $\begin{array}{l}\text { What was your role in the production? } \\
\text { What in your opinion did the process you under- } \\
\text { went contribute? } \\
\text { What do you feel developed in you? }\end{array}$ \\
\hline Local question & $\begin{array}{l}\text { Question as a result of the information in the A. } \\
\text { far-reaching question }\end{array}$ & $\begin{array}{l}\text { What in this course caused this development? } \\
\text { Did this change something in your nature? }\end{array}$ \\
\hline Example question & $\begin{array}{l}\text { The interviewer asks for examples for clarify- } \mathrm{A} \text {. } \\
\text { ing the descriptions }\end{array}$ & In what do you think you improved the most? \\
\hline Experience question & $\begin{array}{l}\text { The interviewees are asked to describe an A. } \\
\text { experience they underwent and to contribute B. } \\
\text { from their personal experience }\end{array}$ & $\begin{array}{l}\text { What changes do you feel in your ability? } \\
\text { How do you think this can be improved even } \\
\text { more? }\end{array}$ \\
\hline
\end{tabular}

44], which is based on the analysis of thematic units [45] that are defined by the contents told in them. The content analysis process includes a search for components that are repeated in the collected data. These components are defined as categories for analysis.

We searched for prominent and interesting components that were repeated at high frequency. The students' sayings were encoded and analyzed according to Strauss and Corbin [46], and categories that describe their sayings were created. These components were defined as categories for analysis. The answers to the interviews were given to ten referees from the field of education who were asked to match between the students' answers and the chosen categories in order to verify the reliability of the categories in each question. Changes were made in the matching between the answers and the categories according to the referees' answers.

\subsubsection{Data Analysis}

Quantitative data analysis was performed according to the frequency of the appearance, i.e. the number of appearances of each category in the analysis units, and the frequency of the appearance of all the categories.

\subsubsection{Reliability and Validity}

Reliability deals in the possibility of replicating scientific findings [38]. External reliability refers to the repetition of the research by another researcher and internal reliability refers to the extent to which another research and the same instruments and methods can yield identical results. Reliability in a qualitative research is not compatible with reliability in a quantitative research, and is based on the extent of being able to rely on the collected data. The reliability of the qualitative part of the research was maintained by the following:

1) Choosing informants: Informants are the studied population. The students who participated in the experience process are most suitable for supplying the qualitative information on the process they underwent through their experience in community television $[47,48]$.

2) Audit trail: A detailed recording of all the details related to the research in general and the ways of collecting the information and the data analysis process was conducted in order to enable other researchers to reconstruct the details of the research.

3) Mechanical reporting of the data: The interviews were recorded on a tape recorder, which strengthens the reliability of the results [38].

Validity refers to the verity of the scientific explanations for a social situation, phenomenon or curriculum. Internal validity refers to the correspondence between the results and the subjects' reality. The presence of the researchers during the interview and use of documentation methods such as a tape recorder are among the weaknesses of the internal validity. However, this is also the source for the strength of the method. The interviews were held in the students' natural location in a manner that reflects their life reality. The research validity stemmed from the manner of collecting the information:

1) Internal validity: Use of several research instruments that enable crossing and verification of the data $[43,44,48]$. The data obtained in the interview were compared with the quantitative data in order to verify the validity of the findings.

2) Content validity, expert referees: The interviews were given to referees from the field of education and after receiving an explanation on the essence of the research they matched between the students' answers and the chosen categories. Changes were made in the choice of categories, according to the referees' answers.

Qualitative research necessitates use of ethics to protect the privacy of the subjects, exhibit sensitivity towards them and construct the researcher's credibility $[49,50]$. In the present research the encounter between the students and the work with them was based on personal relations between the researcher and the subject and the closeness between them. The following steps were taken to preserve the rules of ethics in the research:

1) The subjects knew that the research examines the learning process via community television and expressed their consent to participate.

2) The subjects used fictitious names in all questionnaires and interviews and remained anonymous. They were not exposed with their full na- mes or any other detail that could indicate their identity. 


\subsection{The Research Procedure}

The research was divided into two parts:

Part A

Job analysis was performed for role holders in community television in order to locate the psychological variables that characterize each experience.

1) Mapping the experiences in community television (role holders) by analyzing roles (questionnaires and interviews).

2) Defining the different levels of experience in community television according to role holders (director, editor, photographer, actor) based on analysis of the roles after their performance.

Part B

1) Pre-test.

2) Intervention in learning via students' experience in community television at a scope of 90 hours.

3) Production of a product (report) by the students after their experience in community television.

4) Post-test.

5) Holding interviews for confirmation of the quantitative research.

Analysis of the roles was divided into several stages: A. Survey; B. Interview; C. Questionnaire; D. Analysis of the questionnaire; E. Questionnaire for creating ranking between the experiences:

1) Survey: Surveys were administered to about 45 community television coordinators in which they were asked: what are the four most significant roles in community television in your settlement? The results of the surveys indicated that the most significant or the most prominent roles are: directors, actors, editors and photographers.

2) Interview: Fifty role holders (professionals) from the field of television (12 directors, 15 actors, 10 editors and 13 photographers) were interviewed and were asked in free form, what personal abilities are required for success in their role. The interviews were held according to the rules of the open ethnographic interview [42]. Such interviews are based on friendly, harmonious and informal relations and enable free flow of information. A long list of personal abilities necessary for success in the role was then prepared.

3) Questionnaire: A questionnaire was administered for creating a ranking between the experiences. After we had the four roles (experiences) that were defined as most significant and prominent, a questionnaire was administered to the same 45 community television coordinators, in which they were asked to rank the experiences and indicate which role requires more creativity and which requires less creativity.

The next stage included the intervention program underwent by the subjects and testing their level of creativity before and after the program. This stage was also di- vided into several parts: A. Pre-test; B. Learning the television production processes; C. Experience in production roles; D. Producing a movie; E. Post-test; F. Holding interviews. 150 subjects comprised the research group and 50 students comprised the control group. They were all administered the tendency to creativity questionnaire [1].

We did not ask the students to indicate their name, so that they would feel free to report their true feelings, since this is a very personal questionnaire, and we were afraid they would not report their true feelings but rather what they think is expected of them. We therefore asked them to identify themselves by a fictitious name. We also asked unimportant details such as the number of brothers and sisters and the shoe size so that we could match between the pre and post-test.

Analysis of variance of the questionnaires indicated no significant differences between the groups, and a normal distribution. It may be assumed that the groups are homogenous and that the subjects began at a similar starting point.

Learning the television production processes lasted for eight months. Before beginning the studies, the students were told that the goal of the learning is to experience processes of television production and that at the end of the studies they would have to produce their own work, a movie common to the entire production team that will include a director, photographer, actor and editor. The students experienced 24 2-hour meetings during these eight months, i.e. a total of 60 hours. At the end of the lessons they received tasks whose goal was to experience the diversity of issues and roles that were studied.

Researches indicate that significant learning takes place via methods that develop activity integrated with learning tasks, stimulating learning that integrates illustrations, practicing the content of learning and educational experiences that encourage in-depth learning [51-54]. The students experienced a diversity of roles from the field of production in order to produce the final product, a movie.

In the first stage they had to choose a role. The principle of personal choice enables the adolescents to choose the field in which they want to deal, the type of activity and the diversity of activities. The rationale behind the choice is the assumption that free choice promotes the creation of real motivation and can strengthen the youths' decision making process and their taking responsibility for their choice. Since the choice of the role is influenced by the personal ability, professional and personal tendency and goals and values, the principle of free choice enabled all students to choose their role and field of activity according to their ability, tendency, personality and goals. The students chose the role they would experience (director, editor, photographer, actor) and the 
experience began. The experience took place between the lessons, in tasks they received.

Production of the final movie was the peak activity in the learning process. All role holders participated in the production of the movie, where each comprised a complementary part in the production process. Production of the movie also included experiences not examined in the present research (producer, investigator, sound person, script writer). The production included the directing of the movie, photographing it, acting and editing. The learning process and the reaching of conclusions were performed in real time, during the production via instruction by the coordinator and in collaboration with the director.

135 students from the research group were tested individually in the post-test questionnaire, in role analysis and in a self-image questionnaire (15 students who participated in the first part of the research were absent from the second part, 10 were absent since one group closed during the year and 5 for personal reasons). 40 students from the control group were individually tested in the questionnaires for measuring the variables chosen in the role analysis and in the self-image questionnaire (10 students were absent for personal reasons). The order of the tests was identical for all subjects.

Of the 135 students in the research group who were tested a second time, 119 remained to the end, since 16 questionnaires were invalidated or because of incomplete answering of the questionnaire or because of experiencing a role not included in the research. Of the 40 students in the control group, 38 remained since 2 questionnaires were invalidated or because of incomplete answering of the questionnaire.

After the learning and the production ended, 61 students were interviewed. Each interview lasted about 30 minutes. The students were asked 17 questions referring to the process they underwent, which tried to clarify their feelings, what they thought the process developed, what in the process caused the development, did something change in their ability, what in the course caused the change, etc. The interviewer presented general questions as well as leading questions in order to guide the students. The interviews were recorded on a tape recorder and were later transcribed. The interviews were conducted by teachers with experience in educational work with youths who received written and oral instruction pertaining to the interview design, being strict about a pleasant atmosphere, eye contact with the interviewee, directing the students, expected answers and how to refer to them.

\section{Results}

The research was carried out in two stages. In the first stage a comparison was made between the subjects who experienced community television production processes (the research group) and subjects who did not experience these production processes (the control group). The groups were matched in terms of the students' level and their socioeconomic level.

The second stage was intended for the 119 students who experienced the television production processes. These students included 71 boys and 48 girls and were divided into four role holders according to their experience in the production process: director, photographer, actor and editor. The boys were divided into 19 directors, 12 editors, 18 photographers and 22 actors and the girls into 9 directors, 15 editors, 14 photographers and 10 actors.

\subsection{Tendency to Creativity}

The variable tendency to creativity was divided into the measures curiosity and creativity. The means of the curiosity measure before and after the students' experience in community television production among the research group are presented according to the nature of the role (type of experience). The differences in the level of curiosity before and after the experience in community television in each of the types of experience (director, editor, photographer, actor) were examined by a $t$ test for dependent measurements. A significant difference was found in the means of the curiosity measure before and after the experience in community television production in each of the experience types: director $(p<0.001$, one-way, $t(27)=-4.49)$, editor $(p<0.001$, one-way, $t(26)$ $=-7.29)$, photographer $(p<0.001$, one-way, $t(31)=$ $-7.39)$, and actor $(p<0.001$, one-way, $t(31)=-5.11)$. Thus, all four roles resulted in a higher level of curiosity after the experience in community television compared to its level before the experience.

The means of the originality measure before and after the students' experience in community television production according to the nature of the role (type of experience) are presented in Table 2. The differences in the level of originality before and after the experience in community television in each of the types of experience (director, editor, photographer, actor) were examined by a $t$ test for dependent measurements. A significant difference was found in the means of the originality measure before and after the experience in community television production in each of the experience types: director $(p<0.001$, one-way, $t(27)=-6.36)$, editor $(p<0.001$, one-way, $t(26)=-5.19)$, photographer $(p<0.001$, one-way, $t(31)=-7.89)$, and actor $(p<0.001$, one-way, $t(31)=-5.21)$. Thus, all four roles resulted in a higher level of originality after the experience in community television compared to its level before the experience.

The means of the general tendency to creativity measure before and after the experience in community television according to the nature of the role (level of experience) are presented in Table 3. The differences in the level of the tendency to creativity before and after the 
experience in community television in each of the types of experience (director, editor, photographer, actor) were examined by a $t$ test for dependent measurements. A significant difference was found in the means of the tendency to creativity measure before and after the experience in community television production in each of the experience types: director $(p<0.001$, one-way, $t(27)=$ $-6.41)$, editor $(p<0.001$, one-way, $t(26)=-5.53)$, photographer $(p<0.001$, one-way, $t(31)=-7.97)$, and actor $(p<0.001$, one-way, $t(31)=-5.16)$. Thus, all four roles resulted in a higher tendency to creativity level after the experience in community television compared to its level before the experience.

The differences in the tendency to creativity level among the students in the control group before and after the period during which the students in the research group experienced community television were examined by a $t$ test for dependent measurements. A significant difference was found in the means of the measure of curiosity among the students in the control group in the period before and after the students in the research group experienced community television $(p<0.001, t(37)=$ 3.47). Furthermore, the tendency to creativity level was found to be higher before the experience in community television among the research group $($ mean $=3.85)$ compared to after the period of the experience in community television ( mean $=3.68)$.

No significant difference was found in the means of the measure of originality or the means of the general tendency to creativity among the students in the control group in the period before and after the students in the research group experienced community television production $(p<0.05)$.

One-way analysis of variance (ANOVA) was performed. No significant differences ( $p>0.05$ ) were found in the level of the self-image (personal, social, moral and general measure), the tendency to creativity (curiosity, originality and general measure), leadership (charisma, inspiration, individualism, intellectual stimulation and general measure), motivation to give, emotional intensity and motivation between the students according to their choice of role.

\subsection{Interviews}

The qualitative findings of the research were obtained

Table 2. Originality, means among students who experienced community television production according to the nature of the role

\begin{tabular}{lccccc}
\hline \multicolumn{1}{c}{ Role } & $N$ & Mean before & $S D$ & Mean after & $S D$ \\
\hline Director & 28 & 3.22 & 0.53 & 3.97 & 0.52 \\
Editor & 27 & 3.15 & 0.69 & 3.88 & 0.56 \\
Photographer & 32 & 3.08 & 0.50 & 3.91 & 0.58 \\
Actor & 32 & 2.93 & 0.73 & 3.56 & 0.48 \\
\hline
\end{tabular}

through an interview held with the students after their experience. The goal of the interview was to compare the quantitative results and the students' subjective feelings as well as to find out what in their opinion contributed to their development and improvement. The students' frequent answers are presented in Table 4.

\section{Discussion}

This research focused on the relationship between students' experience in community television and a change in their creative thinking ability. The goal of the research was to examine whether experience in community television develops the creative thinking ability in the students and whether different experiences have different effects on the creative thinking ability as presented in the role analysis. The tendency to creativity variable was divided into two factors, curiosity and originality.

Curiosity: The curiosity factor included statements that refer to the desire to know, to learn new things and to be open to the experiences of others. It was found that the level of curiosity was higher after the experience in community television than before the experience in all four experiences, with no difference between the different experiences.

Curiosity is perceived as a motive force in the child's development [55], as incentive for learning achievements [56] and as a major lever for advancing scientific discoveries [57]. The learning process by means of experiencing community television developed more curious students. Their level of curiosity increased, including the need to ask questions and the need to know. Experience in community television enables coping with situations of curiosity in each of the roles. Curiosity is a type of inquiry, a desire to know more, to discover. Maw and Maw [58] defined curiosity as a combination of a positive reaction to new, strange or mysterious events while investigating them, the need or aspiration to know more about yourself or your environment, surveying the environment with the aim of finding new experiences, focusing on the examination and inquiry of stimuli in order to know more about them. The students experienced roles that created the need for curiosity.

Originality: The originality factor included statements that refer to original thinking, flexible and branching thinking, thought fluency and the desire to remember new

Table 3. Tendency to creativity, means mong students who experienced community television production according to the nature of the role

\begin{tabular}{cccccc}
\hline Role & $N$ & Mean before & $S D$ & Mean after & $S D$ \\
\hline Director & 28 & 3.35 & 0.51 & 4.07 & 0.46 \\
Editor & 27 & 3.24 & 0.66 & 3.95 & 0.51 \\
Photographer & 32 & 3.17 & 0.57 & 4.02 & 0.54 \\
Actor & 32 & 3.02 & 0.72 & 3.66 & 0.47 \\
\hline
\end{tabular}


Table 4. A summary of the students' frequent answers in the interviews is presented according to the type of experience

\begin{tabular}{|c|c|c|c|c|c|}
\hline Question & Director & Editor & Photographer & Actor & $\begin{array}{l}\text { Answer of the } \\
\text { majority }\end{array}$ \\
\hline $\begin{array}{l}\text { What in your opin- } \\
\text { ion does the proc- } \\
\text { ess contribute? }\end{array}$ & Self-confidence & $\begin{array}{l}\text { Understanding/ } \\
\text { information }\end{array}$ & Understanding/information & $\begin{array}{l}\text { Understand- } \\
\text { ing/information }\end{array}$ & $\begin{array}{l}\text { Understanding/ } \\
\text { information }\end{array}$ \\
\hline $\begin{array}{l}\text { What developed in } \\
\text { you? }\end{array}$ & Understanding/learning & $\begin{array}{l}\text { Understanding/ } \\
\text { learning }\end{array}$ & Understanding/learning & $\begin{array}{l}\text { Understanding } \\
\text { /learning }\end{array}$ & $\begin{array}{l}\text { Understand- } \\
\text { ing/learning }\end{array}$ \\
\hline $\begin{array}{l}\text { What in the course } \\
\text { caused the devel- } \\
\text { opment? }\end{array}$ & The cooperation & The role & The role & The role & The role \\
\hline $\begin{array}{l}\text { Did this change } \\
\text { something in your } \\
\text { personality? }\end{array}$ & Self-confidence & $\begin{array}{l}\text { Express an } \\
\text { opinion, par- } \\
\text { ticipate more }\end{array}$ & Self-confidence & Self-confidence & Self-confidence \\
\hline $\begin{array}{l}\text { How do you know } \\
\text { that this caused a } \\
\text { change? }\end{array}$ & Feel & $\begin{array}{l}\text { Feel, am more } \\
\text { interested in } \\
\text { issues }\end{array}$ & Feel & Feel & Feel \\
\hline $\begin{array}{l}\text { What in the course } \\
\text { caused the change? }\end{array}$ & Performing the role & $\begin{array}{l}\text { Performing the } \\
\text { role }\end{array}$ & Performing the role & $\begin{array}{l}\text { Performing the } \\
\text { role }\end{array}$ & $\begin{array}{l}\text { Performing the } \\
\text { role }\end{array}$ \\
\hline $\begin{array}{l}\text { Did this change } \\
\text { something in your } \\
\text { ability? }\end{array}$ & Knowledge & Knowledge & Knowledge & Knowledge & Knowledge \\
\hline $\begin{array}{l}\text { How do you know } \\
\text { that it changed? }\end{array}$ & Feel & Feel & Feel & Feel & Feel \\
\hline $\begin{array}{c}\text { In what do you feel } \\
\text { you improved the } \\
\text { most? }\end{array}$ & Self-image, originality & Self-image & Self-image & Self-image & Self-image \\
\hline $\begin{array}{l}\text { How do you feel? } \\
\text { According to what? }\end{array}$ & $\begin{array}{c}\text { Am not afraid, feel confi- } \\
\text { dence }\end{array}$ & $\begin{array}{l}\text { Am not afraid, } \\
\text { feel confidence }\end{array}$ & Am not afraid, feel confidence & $\begin{array}{l}\text { Am not afraid, } \\
\text { feel confidence }\end{array}$ & $\begin{array}{l}\text { Am not afraid, } \\
\text { feel confidence }\end{array}$ \\
\hline $\begin{array}{l}\text { How is the im- } \\
\text { provement ex- } \\
\text { pressed? }\end{array}$ & $\begin{array}{c}\text { When I am with people I } \\
\text { feel openness and im- } \\
\text { provement }\end{array}$ & $\begin{array}{l}\text { By the profes- } \\
\text { sional work }\end{array}$ & $\begin{array}{l}\text { I have confidence that when I } \\
\text { am with people I feel openness } \\
\text { and improvement }\end{array}$ & $\begin{array}{l}\text { By the profes- } \\
\text { sional work }\end{array}$ & $\begin{array}{l}\text { When I am with } \\
\text { people I feel } \\
\text { openness and } \\
\text { improvement }\end{array}$ \\
\hline $\begin{array}{l}\text { What changes do } \\
\text { you feel in your } \\
\text { ability following } \\
\text { the improvement? }\end{array}$ & $\begin{array}{c}\text { Am not ashamed, confi- } \\
\text { dence }\end{array}$ & $\begin{array}{l}\text { Feel greater } \\
\text { efficacy }\end{array}$ & Am not ashamed, confidence & $\begin{array}{l}\text { Feel greater } \\
\text { efficacy }\end{array}$ & $\begin{array}{l}\text { Feel greater effi- } \\
\text { cacy }\end{array}$ \\
\hline $\begin{array}{l}\text { How can this be } \\
\text { improved further? }\end{array}$ & $\begin{array}{l}\text { Exposure, training, and } \\
\text { experience }\end{array}$ & $\begin{array}{l}\text { Exposure, } \\
\text { training, and } \\
\text { experience }\end{array}$ & $\begin{array}{l}\text { Exposure, training, and experi- } \\
\text { ence }\end{array}$ & $\begin{array}{l}\text { Exposure, } \\
\text { training, and } \\
\text { experience }\end{array}$ & $\begin{array}{l}\text { Exposure, train- } \\
\text { ing, and experi- } \\
\text { ence }\end{array}$ \\
\hline $\begin{array}{l}\text { What is the second } \\
\text { concept in which } \\
\text { you feel an im- } \\
\text { provement? }\end{array}$ & Motivation to give & Motivation & Motivation to give, motivation & Motivation & Motivation \\
\hline $\begin{array}{l}\text { How do you feel } \\
\text { that it improved? }\end{array}$ & $\begin{array}{l}\text { I have a desire to do } \\
\text { things }\end{array}$ & $\begin{array}{l}\text { I have a desire } \\
\text { to do things }\end{array}$ & I have a desire to do things & $\begin{array}{l}\text { I have a desire } \\
\text { to do things }\end{array}$ & $\begin{array}{c}\text { I have a desire to } \\
\text { do things }\end{array}$ \\
\hline $\begin{array}{l}\text { What in the course } \\
\text { caused this to im- } \\
\text { prove? }\end{array}$ & $\begin{array}{l}\text { The role I } \\
\text { was given }\end{array}$ & $\begin{array}{l}\text { The role I was } \\
\text { given }\end{array}$ & The role I was given & $\begin{array}{l}\text { The role I was } \\
\text { given }\end{array}$ & $\begin{array}{l}\text { The role I was } \\
\text { given }\end{array}$ \\
\hline $\begin{array}{l}\text { What changesdo } \\
\text { you feel in your } \\
\text { ability? }\end{array}$ & Professional abilities & $\begin{array}{l}\text { Professional } \\
\text { abilities }\end{array}$ & Professional abilities & $\begin{array}{l}\text { Professional } \\
\text { abilities }\end{array}$ & $\begin{array}{l}\text { Professional } \\
\text { abilities }\end{array}$ \\
\hline
\end{tabular}

things. The level of originality was higher after the experience in community television than before the experience in all four experiences, with no difference between the different experiences. "When making movies there are no rules, there are only sins and the greatest sin of all is: boredom." For the movie to be interesting the production team must exhibit a great degree of originality. Originality is the sophistication of something existing, the ability to see something that we knew existed for generations in reality from a new point of view. The students experienced roles that created a need for originality.
Tendency to creativity (general measure): The level of the tendency to creativity was higher after the experience in community television than before the experience in all four experiences, with no difference between the different experiences. Creative thinking can be taught by means of cultivating thinking patterns. Researches indicate an improvement in the tendency to creativity by training and the development of the abilities of creative thinking by means of different teaching methodologies [29]. The students who experienced community television developed their tendency to creativity after the experience 
thanks to the teaching methodologies which they experienced when fulfilling their roles.

The goal of education is to educate people who are able to create new things and not just repeat the actions of previous generations: creative people, inventors, discoverers and scientists. We need active students who learn to search and find on their own and by spontaneous activity as well as by material edited by us, so that they will be able to differentiate between what has been proven and the first idea that came to their mind. This is how the students who experienced production roles created a new creation and developed a tendency to creativity.

The research results can be concluded as follows: Community television is a learning environment that enables all students to experience a role according to their talents and abilities. Experience in this environment develops the self-image regardless of the type of experience. The director, editor, photographer and actor all improved their level of self-image, with no differences between them.

A learning environment that enables a group of students to each experience a different role and enables them to contribute according to their desire and belief in their ability, with a common goal, affords the participants pride in the process and creates an added value that comprises a very important factor for the process of consolidating the self-image. The improvement in the self-image stemmed from the students' good feeling upon finishing the task. Since different experiences are suitable for different students [59], the students will develop their selfimage by fulfilling a role after having completed the expectations of them within the framework of their work, regardless of the role.

The students' experience in community television has a positive influence on the tendency to creativity, in all experienced roles: director, editor, photographer, and actor. Many psychological theories present ways for actualizing the creative ability (experiential learning, learning from experience, leaning by doing, autonomous learning, the multiple intelligences theory, open tools). Community television enables a total learning environment that unites the abovementioned theories.

Experience in community television production roles, similarly to the constructivist theory, is focused on the students, their choice and experience. However, it sets clear boundaries within the framework of the production roles that enable a uniform and clear direction of action on the way to achieve the product. This environment invites open learning on the one hand and a clear and directing framework on the other hand, that enables the production of a product, a feeling of success and completion.

Experience in a defined task that enables the students acquaintance with the role, its goals and products together with the belief that they can indeed realize it is significant for developing the creative thinking ability.
When the students perform a task and succeed in it, where the combination of all the efforts leads to a higher product (a movie), the success of the entire group joins the success of the individual, thus strengthening the creative ability. The students view the production of the movie as their personal success and thus both the performance of a defined role together with the ability to bring it to a finish as well as the cumulative success expressed by the finished movie joins their achievements and gives them power. When I have a part in the success of the entire group, my contribution becomes much more significant. The ability for creative thinking increases and is strengthened both because of my individual success in performing my role and because of my success as part of a group with a common goal. The individuals' success in fulfilling their role is strengthened when they acts as part of a group with a common task.

The constructivist theory espouses the idea that students construct their knowledge from their experience, through the experience. The present framework focuses on the students. The students choose the learning activities, and the learning goals and learning environment are adapted to the students' needs via independent learning and self-structuration of the knowledge. Experience in community television, similarly to the constructivist theory, enables the students to construct their knowledge while experiencing production roles. It is student-focused and the students choose the role, the learning environment and the experience environment within which they will perform their part in the production. The students are active learners who learn by experience, cope and strive for meaning. The knowledge is tested in their conscious based on their experience in the activity in the production roles and their interpretation and knowledge structure become more sophisticated.

The constructivist theory claims that people understand the world differently because they have different past experiences. So also in community television, the role holders see their goal differently from each other because of the different experiences in the production process. Correct teamwork, shared production and clear division of roles enables the production people to sit together, understand each other and the other's importance and role and thus achieve a shared product.

"We are not searching for what the students can repeat, but rather what they can create, demonstrate and present." The experience in community television enables the students to create, demonstrate and present according to the role they chose. This experience affords the student an opportunity to construct knowledge by asking questions in the process of carrying out an investigation, questions that pertain to the process of producing the movie, to the photography angles, to the process of editing and to the form of acting, to collect information via an in-depth investigation and the correct work of the di- 
rector and activation of abilities that characterize the role in order to connect between asking the questions and collecting the information on the way to produce the movie. The experience is based on the principles of constructivist teaching but contrary to constructivist teaching this learning is characterized by a clear and absolute framework for the construction of knowledge. The students are on the one hand free to choose the role and how to obtain the information, but on the other hand are directed by the production framework that affords clear and uniform (production) tools on the way to the product.

Experience in community television production roles enables the students to choose both the theme of their movie and the active part they will take in the learning process. The students investigate and examine the relevant information for the idea that leads to the movie and in the end choose to produce one part. They must present a diversity of opinions for every truth, must listen to more than one side in order to be objective and create trust in the viewers. If the teaching is supposed to cultivate understanding, it must come to the students and meet them in the place they are found intellectually. The results of the present research indicate that experience in community television enables all students to choose the role they will experience according to their personal tendencies, intelligences that characterize them out of the multiple existing intelligences, and personal abilities. The students learn through experience, learn from experience, learn while presenting the products to the class and their evaluation is carried out as part of the learning process and using the means they used during the production process (not by an exam).

Learning by experiencing community television production is learning with an open tool. When working with open tools, the personal responsibility for learning increases, with the development of abilities and skills for direction towards independent learning. Technology enables active construction of knowledge. Active involvement in the construction, alone or with cooperation, may influence the mind. Constructing programs, for example in the computer, forces the students to significantly connect between the items of their knowledge. Students who write a hypertext lead their audience to understand an idea through connections they planned. Organizing the knowledge in a meaningful manner cultivates the selfunderstanding of the writer. So also in community television: the students, each in the role they chose, lead the viewer via the product they created (the movie), while connecting between the different items of information to the main idea and passing through the contexts they planned in order to best present the theme of the movie.

The technological revolution which is taking place is accompanied by a pedagogical and social revolution that includes placing the students in the center of the learning process, taking into account the differences between stu- dents and their social needs, using alternative modes of evaluation and greater freedom of choice for the students. Experience in community television places the students in the center of the learning process and allows them to choose from a variety of experiences in order to enable a constructivist learning process according to the students' wishes and fields of interest. Learning in community television enables use of an open tool, but with clear boundaries. It affords a framework that is interactive, open and supplies experiences with expression of multiple intelligences and active learning on the one hand, and on the other hand the roles of all role holders are clear, defined and structured, the framework is uniform and the goal of all role holders is to achieve a particular product - the movie.

The present research proposes an open learning environment that enables the student imagination, experimenting and action with a feeling of "no limits." The learning environment focuses on the students and the students choose the learning activities and learning goals by independent learning and self-structuration of the knowledge. The entire process converges within the framework of a clear and structured production that enables the students to express abilities, tendencies and intelligences, through interaction with members of their group, according to their roles and abilities, while experiencing existing and defined roles and producing a product - the movie - according to existing rules. The environment enables the students to develop traits, tendencies and abilities. The students feel that they can express themselves in any way they choose, but are placed within a directing framework that enables a rapid product and a feeling of success. This leads to an improvement in the self-image, tendency to creativity, motivation to give, emotional intensity and motivation. This environment invites open learning that enables experience through choice on the one hand and on the other hand a clear and directing framework that enables production of a product as part of a group which comprises empowerment for the feeling of success and thus improvement of the creative thinking ability.

The students' experience in community television has a positive influence on the tendency to creativity (curiosity, originality and general creative tendency) in all experience roles: director, editor, photographer, and actor. The students' experience in community television has a positive influence on the extent of intellectual stimulation in all experience roles: director, editor, photographer, actor, where the degree of improvement was greater among those who experienced the role of director or photographer.

The present research leads to several educational conclusions. Experience in community television production enabled the students' active learning by which they developed their tendency to creativity. This learning environment was found suitable for learning via active learn- 
ing by adapting the curriculum to needs of the individual and enabling free expression, learning, experience and action.

\section{REFERENCES}

[1] T. J. Rookey, "Validation of Creativity Test," Journal of Creative Behavior, Vol. 8, No. 3, 1974, pp. 211-213.

[2] B. Offir, "Analysis and Decision Making Models in the Process of Assimilation of Change and Innovation in Learning System,” In: P. B. Richards, Ed., Global Issues in Higher Education, Nova Science, New York, 2007, pp. 237-266.

[3] B. Offir and M. Aflalo, "Learning by Doing the Influence of Students' Experience in Community Television Production on Personality Variables," Education Information Technology, Vol. 13, No. 1, 2008, pp. 3-15.

[4] T. I. Lubart, "Creativity," In: R. J. Sternberg, Ed., The Nature of Creativity, Cambridge University Press, New York, 1994, pp. 325-339.

[5] R. J. Sternberg, "A Three-Faceted Model of Creativity," In: R. J. Sternberg Ed., The Nature of Creativity, Cambridge University Press, New York, 1988, pp. 11-38.

[6] R. J. Sternberg and T. I. Lubart, "An Investment Theory of Creativity,” Human Development, Vol. 34, No. 1, 1991, pp. 1-32.

[7] R. J. Sternberg and T. I. Lubart, "Investing in Creativity," American Psychologist, Vol. 51, No. 7, 1996, pp. 677688.

[8] M. A. Flaherty, "The Effects of a Holistic Creativity Program on the Self Concept and Creativity," In: R. J. Sternberg Ed., Handbook of Creativity, Cambridge University Press, New York, Vol. 14, 1992, pp. 165-171.

[9] J. P. Guilford, "Traits of Creativity," In: H. H. Anderson Ed., Creativity and its Cultivation, Harper and Row, New York, 1959, pp. 171-173.

[10] M. Lowenfeld, "Drama and Children Play," In: J. Hodgson Ed., The Uses of Drama Acting, London, Methuen, 1972, pp. 34-55.

[11] E. P. Torrance, "Exploration in Creative Thinking," Education, Vol. 24, No. 1, 1960, pp. 216-220.

[12] E. P. Torrance, "Education and the Creative Potential," University of Minnesota Press, Minneapolis, 1963

[13] E. P. Torrance, "Torrance Tests of Creative Thinking: Norms Technical Manual," Personnel Press, Princeton, 1966.

[14] H. Gardner, "Multiple intelligences: The Theory in Practice," Basic Books, New York, 1992.

[15] D. L. P. Nilsen, "Humor and Creativity-Humorous Names: Some Creative Processes," The Creative Child and Adult Quarterly, Vol. 16, No. 3, 1991, pp. 175-180.

[16] C. P. Smith, "Reliability Issues," In: C. P. Smith, Ed., Motivation and Personality, Cambridge University Press, New York, 1992, pp. 126-139.

[17] F. Barron, "Putting Creativity to Work," In: R. J. Sternberg
Ed., The Nature of Creativity, Cambridge University Press, New York, 1991, pp. 43-45.

[18] G. J. Feist. "The Influence of Personality on Artistic and Scientivity," In: R. J. Sternberg Ed., Handbook of Creativity, Cambridge University Press, New York, 1999, pp. 273-298.

[19] B. J. King and B. Pope, "Creativity as a Factor in Psychological Assessment and Health Psychological Functioning," Journal of Personality Assessment, Vol. 72, No. 2, 1999, pp. 200-207.

[20] C. W. Taylor, "Various Approaches to and Definitions of Creativity," In: R. J. Sternberg, Ed., The Nature of Creativity, Cambridge University Press, Cambridge, 1991, pp. 99-124.

[21] E. P. Torrance, "The Nature of Creativity as Manifested in its Testing," In: R. J. Sternberg, Ed., The Nature of Creativity, Cambridge University Press, New York, 1991, pp. 76-98.

[22] R. S. Mansfield and T. V. Buss, "The Psychology of Creativity and Discovery," Nelson-Hall, Chicago, 1981.

[23] D. Perkins, “The Mind's Best Work," Harvard University Press, Cambridge, 1981.

[24] J. Larkin, "The Role of Problem Representation in Physics," In: D. Gentner and A. S. Stevens Eds., Mental Models. Hillsdale, Lawrence Erlbaum, 1983, pp. 75-100.

[25] A. H. Schoenfeld and D. J. Herrmann, "Problem Perception and Knowledge Structure in Expert and Novice Mathematical Problem Solvers," Journal of Experimental Psychology: Learning, Memory and Cognition, Vol. 8, No. 5, 1982, pp. 484-494.

[26] T. M. Amabile, "The Social Psychology of Creativity," Springer, New York, 1983.

[27] C. Chin and D. E. Brown, "Learning in Science: A Comparison of Deep and Surface Approaches," Journal of Research in Science Teaching, Vol. 37, No. 2, 2000, pp. 109-138.

[28] J. P. Guilford, "Creativity: A Quarter Century of Progress," In: I. A. Taylor and J. W. Getzels, Eds., Perspectives Creativity, Aldine, Chicago, 1975, pp. 35-39.

[29] L. H. Rose and H. T. Lin “A Meta Analysis of Long Term Creativity Training Programs,” In: S. J. Parnes, Ed., Source Book for Creative Problem Solving, Creative Educational Foundation, Buffalo, 1992, pp. 124-131.

[30] J. L. Adams, "Conceptual Blockbusting: A Guide to Better Ideas,” W. H. Freeman, Ed., New York, 1974.

[31] E. De Bono, "Lateral Thinking: Creativity Step by Step," Harper and Row, New York, 1970.

[32] D. Perkins, "Creativity by Design," Educational Leadership, Vol. 42, No. 1, 1984, pp. 8-25.

[33] D. Perkins, "Knowledge as Design," Lawrence Erlbaum, Hillsdale, 1986.

[34] M. Chebaro, "Cross-Cultural Inquiry in Art and Therapy," In: A. Hisch and A. C. Calisch, Eds., Tapestry of Cultural Issues in Art Therapy, Jessica Kingsley, London and Philadelphia, 1998, pp. 229-240. 
[35] R. Courtney, "Re-play: Studies of Human Drama in Education," Oise, Toronto, 1982.

[36] B. J. Fraser, "Grain Size in Learning Environment Research: Combining Qualitative and Quantitative Methods," In: H. C. Waxman and H. J. Walberg Eds., New Directions for Teaching Practice Research, McCutchan, Berkeley, 1999, pp. 285-296.

[37] M. Scriven, "Evaluation Ideologies," In: G. F. Madaus, M. Scriven and D. L. Stuffelebeam Eds., Evaluation Models, Klumer-Jijhoff, Boston, 1991, pp. 229-260.

[38] L. P. Goetz and M. D. Le Compte, "Ethnography and Qualitative Design in Education Research," Academic Press, London, 1984.

[39] C. Pontecorvo and C. Zucchermaglio, "A Passage to Literacy: Learning in A Social Context," In: Y. Goodman Ed., How Children Construct Literacy, International Reading Association, New York, 1990, pp. 59-98.

[40] S. Veenman, "Effects of Multigrade and Multi-Age Classes Reconsidered," Review of Educational Research, Vol. 66, No. 3, 1996, pp. 323-340.

[41] J. Hackman and G. Oldham, "Work Redesign," Addison-Wesley, 1980.

[42] J. P. Spradley, "The Ethnographic Interview," Holt, Rinehart and Winston, New York, 1979.

[43] R. G. Burgess, "Strategies of Educational Research Qualitative Methods," Palmer Press, London and Philadelphia, 1997.

[44] L. Cohen and L. Manion, "Research Methods in Education," Routledge, London, 2000.

[45] K. Krippendorff, "Content Analysis. An Introduction to its Methodology," Beverly Hills, Sage, 1980.

[46] A. L. Strauss and J. Corbin, "Basics of Qualitative Research: Grounded Theory Procedures and Techniques," Newburry Park, Sage, 1990.

[47] R. G. Burgess, "In the Field," Routledge, London and New York, 1997.

[48] C. Glesene and A. Peshkin, "Becoming Qualitative Re- searchers," Longman, New York, 1992.

[49] M. Ponch, "Politics and Ethics in Qualitative Research," In: N. K. Denzin and Y. S. Lincoln, Eds., Handbook of Qualitative Research, Thousand Oaks, Sage, 1994, pp. 183-198.

[50] R. E. Stake, "Case Studies," In: N. K. Denzin \& Y. S. Lincoln, Eds., Handbook of Qualitative Research, Thousand Oaks, Sage, 2000, pp. 236-247.

[51] D. Boud, "Assessment and the Promotion of Academic Values," Studies in Higher Education, Vol. 15, No. 1, 1990, pp. 101-111.

[52] P. Ramsden, "Learning to Teach in Higher Education," Routledge, London, 1992.

[53] P. Ramsden and N. J. Entwistle, "Effects of Academic Departments on Students, Approaches to Studying," British Journal of Educational Psychology, Vol. 51, 1981, pp. 368-383.

[54] K. Sambell, L. McDowell and S. Brown, "“But is it Fair?': An Exploratory Study of Student Perceptions of the Consequential Validity of Assessment," Studies in Educational Evaluation, Vol. 23, No. 4, 1997, pp. 349-371.

[55] D. N. Stern, "The Interpersonal World of the Child," Basic Books, New York, 1973.

[56] H. I. Day, "Curiosity and the Interested Explorer," Performance and Instruction, Vol. 21, No. 4, 1982, pp. 1922.

[57] H. Simon, "The Cat that Curiosity couldn't Kill," Working Paper, Department of Psychology, Carnegie Mellon University, Pittsburgh, 1992.

[58] W. Maw and E. Maw, "An Exploratory Investigation into ihe Measurement of Curiosity in Elementary School Children," Project 80, US Department of Health, Education and Welfare, University of Delaware, Newark, 1964.

[59] P. Haney and J. A. Durlak, "Changing Self-Esteem in Children and Adolescents: A Meta-Analytic Review," Journal of Clinical Child Psychology, Vol. 27, No. 4, 1998, pp. 423-433. 